\title{
60 ROKOV MILLSOVEJ SOCIOLOGICKEJ IMAGINÁCIE: SPOMIENKY A REFLEXIE
}

\author{
DILBAR ALIEVA \\ Sociologický ústav Slovenskej akadémie vied \\ E-mail: dilbaralieva8@gmail.com
}

Moje spomienky na prvé zoznámenie s Millsovou Sociologickou imagináciou siahajú až do roku 1959, ked’ vlastne aj bola vydaná v USA vo vydavatel'stve Oxford University Press (Mills, 1959a). Nejako mimoriadne včasne, teda už v tomto roku sa ocitla v Leninovej knižnici, teda našej slávnej nezabudnutelnej „Leninke“, kde som vtedy trávila celé dni prezenčným štúdiom jej obrovských fondov. Objavila som túto knihu vo vitrínke s novými prírastkami do knižničného fondu, hned’ som ju vybrala z police a na mieste sa do nej začítala. Už z prvého pohladu do jej obsahu mi bolo jasne, že som natrafila na publikáciu, ktorá akoby bola určená pre mňa. Dá sa to pochopit', zoberúc do úvahy, že som vtedy usilovne hladala literatúru pre svoju dizertačnú prácu, ktorá sa mala venovat' kritickému rozboru sociologickej koncepcie Talcotta Parsonsa. Bola som vtedy čerstvou ašpirantkou katedry historického materializmu na filozofickej fakulte Moskovskej univerzity, ktorú som pred rokom absolvovala. Parsonsovi som sa venovala už vo svojej diplomovej práce, ktorú som pripravila a úspešne obhájila pod vedením mojej vzácnej školitelky G. M. Andrejevovej. ${ }^{1}$

Musím však podotknút, že toho Parsonsa som „vyhladala“v knižnici nezávisle na školitelke, ktorá sa o ňom dozvedela odo mňa. Pre zopár sovietskych odborníkov v tom čase možno už nebol celkom neznámou postavou, ale širšia odborná verejnost̉ o ňom ešte nič nevedela. $V$ časopiseckej literatúre o ňom vtedy ešte nepadla ani zmienka. Napokon ani na Západe sa o ňom toho vela nenapísalo. Očividný nedostatok spolahlivej komentujúcej literatúry o Parsonsovi ma naladil na selektívny prístup ku všetkým časopiseckým a knižným novinkám $\mathrm{z}$ americkej sociológie, s ktorými som prišla do styku. Hned som išla hladat v nich nejakú zmienku o Parsonsovi, ale poväčšine to bolo márne. A tu sa zrazu objavuje Sociologická imaginácia od popredného amerického sociológa, ktorý sa nielenže zaoberá všestrannou reflexiou svojej disciplíny, ale v jej rámci sa dokonca špeciálne venuje analýze Parsonsovej koncepcie.

Nebolo si tažké predstavit moju radost’ z kontaktu s touto knihou, ktorá mi prišla pod ruku v pravý čas. A hoci vtedy boli letne prázdniny, rada som každý deň chodila do knižnice, aby som „ustrážila“ túto knihu pred nejakými prípadnými záujemcami. Týchto bolo vždy viac ako exemplárov vzácnych západných vydaní, ktorých mohlo byt jeden - dva

1 Andrejevová Galina Michajlovna (1924-2014) - profesorka Moskovskej štátnej univerzity (MŠU), členka Ruskej akadémie vzdelávania, popredná odborníčka v oblasti sociológie a sociálnej psychológie. Zakladatel'ka a prvá vedúca katedry metodiky konkrétnych sociálnych výskumov na filozofickej fakulte MŠU. 
na Moskvu. Usilovne som študovala nové Millsovo dielo, robila som si z neho poznámky, ktoré by sa mi hodili pre moju dizertačnú prácu. Nádej, že knihu v dohladnom čase vydajú v ruskom preklade, zatial' bola vo hviezdach. Mňa však každodenné čítanie Sociologickej imaginácie vôbec nenudilo. Naopak, mala som z tej knihy nejaký hrejivý pocit. Tak, akoby som zrazu získala nečakanú podporu od neznámeho múdreho kolegu, ktorý v podstate sa usiloval o to isté, čo aj ja. Pocítila som v autorovi nečakaného spolubojovníka, akéhosi „priatela v zbrani“, o autoritu ktorého môžem sa opriet’ v prípade potreby. A takáto potreba vel'mi skoro sa objavila.

Dozvedela som sa, že v najbližšom čase ma čaká na katedre niečo ako atestácia, kde bude treba predložit’ nielen výsledky ašpirantských skúšok, ale aj informovat katedru o stave prípravy mojej dizertačnej práce. Bola to forma priebežnej kontroly ašpirantov, ktorá vzhladom na tému mojej dizertácie mohla pre mňa dopadnút všelijako. Tá sa venovala súčasnej západnej sociológii, a vztah k takým témam na katedre historického materializmu bol ešte dost’ ostražitý. Okrem toho prednost' mali práce, ktoré sa venovali rozboru celej školy alebo smeru v nemarxistickej sociológii. Tie dizertácie, ktoré sa zaoberali „personálnou“ koncepciou jedného autora, k tomu ešte skoro neznámeho, netešili sa vtedy podpore zo strany vedenia katedry. Takže v prípade môjho neúspešného vystúpenia, katedra mohla zamietnut moju pôvodnú tému a namiesto nej mi určit celkom inú. Musela som ešte presvedčit’ vedenie katedry, ako aj jej osadenstvo o dostatočnej významnosti Talcotta Parsonsa ako objektu mojej budúcej dizertačnej práce.

V tejto situácii som sa musela zmobilizovat k eventuálnej obhajobe svojej témy a svojho postupu pri príprave dizertácie. A nová Millsova kniha velmi vhodne zapadla do tohto procesu. Samozrejme, že vtedy som uprela svoju selektívnu „ašpirantskú “ pozornost” prevažne na tie kapitoly Sociologickej imaginácie, ktoré sa zameriavali na charakteristiku dvoch, podla Millsa, hlavných škôl v americkej sociológii. Ostatne témy Sociologickej imaginácie som na nejaký čas nechala stranou. Spomínane školy Mills označil ako „Velkú teóriu“, ktorú podla neho stelesňoval Talcott Parsons a „Abstraktný empiricizmus“, za hlavného zástupcu ktorého prehlásil Paula Lazarsfelda. V skutočnosti sa školy alebo smery s podobnými názvami v americkej sociológii nevyskytovali. Potvrdí to hociktorá klasifikácia sociologických škôl americkej sociológie. Boli to zovšeobecňujúce názvy pre určité zvláštnosti v sociológii, ktoré Mills považoval za „deformácie jednej alebo niekolkých jej tradičných tendencií“ (Mills, 1968, s. 24). Týmto názvom zodpovedal aj obsah spomínaných kapitol, ktorý bol ladený nie ako encyklopedický výklad historického pôvodu a teoretického obsahu každej z tých škôl, ale ako sústavné a cielavedomé odhalenie ich teoretickej alebo metodologickej neúnosnosti.

Získat teda, z toho výkladu nejaké meritórne poznatky, ktoré by niečo dodali k encyklopedickej charakteristike trebárs školy Parsonsa, na ktorej mi vtedy najviac záležalo, sa moc nedalo. Avšak to, čo som načerpala z Millsovej kritickej analýzy tejto školy, mi velmi pomohlo pri profilovaní vlastného stanoviska voči nej. Mills totiž velmi výstižne opísal typologické vlastnosti teoretizovania v duchu „vel'kej teórie“. Útočil na jeho nezrozumitelnost', za ktorou sa nezriedka schovávali dost’ triviálne myšlienky, na jeho „nejasné pohrávanie sa so slovíčkami“ (Mills, 1968, s. 26). Z tohto hladiska Millsova kritika bola dobrou školou pre tých, čo mohli mat’ určité komplexy nielen z Parsonsa, ale aj z iných autorov podobného zamerania. Podporovala v nich nebojácnost' voči údajnej teoretickej nadradenosti takýchto sociológov. 
Ved' aj sama som sa ešte vo svojej diplomovej práci usilovala o to, aby som vysvetlila nezvyklé Parsonsovo pojmoslovie a pretlmočila ho do zrozumitelnej podoby. Nemôžem však povedat', že by som sa celkom stotožnila s Millsom, ktorý neuznával Parsonsovi jeho úsilie o obrodenie teoretickej tendencie v americkej sociológii. Ocenila som však u Millsa to, že mi poukázal na slabé miesta v koncepcii Parsonsa, napríklad na absenciu v jej rámci „systematickej teórie dejín“ (Mills, 1968, s. 40). Imponovalo mi u neho to, že odhalil konzervatívny ideologický obsah Parsonsovej koncepcie, ktorý sa ukrýva za jej zdanlivou teoretickou zložitostou. Tým ma len povzbudil k tomu, aby som hlbšie nazrela do jej vnútra. Dalo by sa povedat', že svojou ostrou kritikou koncepcie Parsonsa ju Mills predsa len celkom neznemožnil. Naopak, tým, že sa jej tak dôkladne venoval vo svojej knihe, jej len pridal na význame, urobil z nej vzor „vellkého teoretizovania“ v sociológii.

V tejto svojej podobe sa už koncepcia Parsonsa stávala objektom, ktorý som mohla prezentovat' osadenstvu katedry historického materializmu, kde som mala v najbližšom čase referovat’ o svojej dizertačnej práci. Napokon som to referovanie úspešne absolvovala a podarilo sa mi vyvolat' u členov katedry skutočný záujem o moju tému a o problémy, ktoré s ňou súviseli. Pochopili, že ide o tému, ktorú predtým v ZSSR ešte nikto nespracoval a nebolo sa o čo opriet’ u domácich autorov. Čo sa týka tých zahraničných, tak medzi nimi som aj poukázala na Millsa a jeho Sociologickú imagináciu. Stručne som charakterizovala túto knihu s osobitným dôrazom na kritiku Parsonsa. Stačilo mi odcitovat najtrefnejšie pasáže z tej kritiky, ako záujem prítomných o môj referát prudko stúpol. Hoci až na G. M. Andrejevovu, ktorá už počas môjho vystúpenia poznamenala, že „práve číta túto knihu“, asi sotva sa niekto z prítomných stihol s ňou oboznámit. Predpokladám, že ten náhly záujem na katedre mohol vzbĺknut už v súvislosti s menom $\mathrm{C}$. W. Millsa, ktorý však už bol dosṫ známym v odborných kruhoch vd’aka popularizácii takých jeho kníh ako Biely golier (1951) a Mocenská elita (1956), ruský preklad ktorej dokonca mal vyjst' už koncom roku 1959. Velký ohlas týchto Millsovych kníh zaručoval zákonitý úspech aj jeho d’alším dielam. Zrejme aj táto okolnost’ prispela k tomu, aby sa na katedre po mojom vystúpení ustálilo dostatočne priaznivé ovzdušie. Napokon mi schválili pokračovanie práce nad už zvolenou témou dizertácie, čo ma vel’mi potešilo. Tá sa uznala za dostatočne nosnú a aktuálnu, najmä ked’ sa Parsonsovi venovali už takí svetoznámi autori, ako C. Wright Mills. Znie to možno paradoxne, ale v danom prípade Sociologická imaginácia C. W. Millsa „zachránila“ Talcotta Parsonsa ako objekt mojej dizertačnej práce.

Písal sa rok 1959 a išlo v podstate o epizódy mojej biografie, ktoré by mali zaujímat' len mňa. Vtedy som to tak aj vnímala. Avšak s odstupom šiestich desatročí ich vidím v nadväznosti na širší historický kontext. Vtedy na okamih som sa stala jedným z tých „miniatúrnych spoločenských priesečníkov biografie a histórie“ (Mills, 1968, s. 11), čo boli nositelmi vzácneho umenia sociologickej imaginácie. $Z$ tohto hladiska by sa spomínané epizódy mojej biografie dalo priradit k spoločensky významnejším udalostiam, hlavným aktérom ktorých bol Mills. A tieto udalosti vo svojom súhrne napokon zostavili určitý historický fenomén, ktorý by sa približne dalo označit ako recepciu Millsovej sociologickej tvorby v Sovietskom zväze v 50.-60. rokoch minulého storočia.

„Približne“ preto, že na plnohodnotnú recepciu bol počet ruských vydaní Millsovych diel príliš nepatrný. Dlhú dobu jedinou preloženou do ruštiny Millsovou knihou bola vydaná v roku 1959 Mocenská elita (Mills, 1959b). Čo sa týka Sociologickej imaginácie, jej včasný výskyt v moskovských knižniciach už v roku 1959 jej nepomohol ani k po- 
hotovému recenzovaniu, ani k referovaniu v odborných časopisoch. Nedošlo vtedy ani k odporúčaniu jej ruského prekladu. Na svoje ruské vydanie (Mills, 1998) si Sociologická imaginácia musela počkat' skoro 40 rokov, už po zániku Sovietskeho zväzu. Preto, ked' ide konkrétne o šírenie v sovietskych odborných kruhoch informácií o Millsovej tvorbe, tak by bolo vhodnejšie použit’ neutrálny vyraz „zavedenie do vedeckého obehu“. V tomto zmysle sa darilo nielen informáciám o Millsovi, ale aj samotnému autorovi. Ten v roku 1960 dokonca navštívil Sovietsky zväz.

Dozvedela sa som o tom náhodou, pár mesiacov po tom „významnom“ pre mňa zasadnutí katedry, a to od svojho školitel’a profesora Momdžjana. ${ }^{2}$ Bola som za nim konzultovat’ svoju dizertačnú prácu a spomenula som mu pritom Millsovu Sociologickú imagináciu ako prípad vydarenej kritiky Parsonsa. Na moje prekvapenie, Momdžjan vedel nielen o tejto knihe, ale aj o jej autorovi, ktorý práve v tom čase navštívil Sovietsky zväz. Počas svojho pobytu v Moskve mal C. W. Mills príležitost’ stretnút sa s poprednými sovietskymi filozofmi a sociológmi, medzi ktorými bol aj môj školitel. O priebehu tohto stretnutia sa zmienil vel'mi stručne. Spomenul si, že sa na stretnutí okrem iného debatovalo o knihe Marxisti, ktorú Mills ešte len pripravoval. Neskôr vraj poslal moskovským kolegom jej rukopis, aby ich oboznámil s jej obsahom. Podla vyjadrení profesora Momdžjana sa dalo usúdit, že ani on, ani jeho kolegovia nesúhlasili s koncepciou tejto Millsovej knihy.

Musím povedat, že vtedy ma ten chládok voči Millsovi trochu zarazil. Vnímala som tieto veci príliš naivne a nechápala som, čo mohli mat̉ naši spoločenskí vedci proti Millsovi. Mohla to však byt' aj ideová nezhoda, aj ostražitost’ voči západnej sociológii, ktorá sa mnohými ešte brala ako niečo celkom cudzie našej spoločenskej vede. Dodajme k tomu aj skutočnost', že i napriek svojmu nespornému záujmu o marxizmus „Mills nebol marxistom“ (Ritzer, 1988, s. 59). Tak ho charakterizovali nielen nezaujatí komentátori, ale aj blízki kolegovia ako napríklad Irving Horowitz. Priznával sa k tomu aj samotný Mills.

V 50. rokoch k nemu v ZSSR pristupovali so stereotypom buržoázneho vedca „zriedkavého druhu“, ktorý sa usiluje podla možnosti „o svedomitú analýzu sociálnopolitických problémov súčasnosti, o správnu faktickú charakteristiku radu skúmaných javov“ (Mills, 1959b, s. 5). Táto charakteristika sa v podstate odvíjala od toho „spásonosného" modelu zahraničných sociológov, vhodných na to, aby s nimi nadväzovali kontakty sovietski vedci, s ktorým v roku 1955 prišlo vedenie sovietskej Akadémie vied. Vtedy predbežne riešilo otázku účasti sovietskej delegácie na Tretom svetovom sociologickom kongrese v Amsterdame. Mohli to byt síce buržoázni vedci, ale takí, ktorí „sa držali pokrokových názorov v oblasti sociológie“ (Firsov, 2001, s. 18). V tých časoch sa Mills ešte zmestil do rámca tohto stereotypu a bol vhodným partnerom pre sovietskych kolegov počas svetových sociologických kongresov. Tak sa s ním na Štvrtom kongrese MSA roku 1959 v Strese zoznámil jeden z „otcov-zakladatelov“ sovietskej sociológie a futurológie E. A. Arab-Ogly (Rossijskaja, 1999, s. 364). Ja však spomínam na to, že to práve ArabOgly nás ešte v roku 1957 zoznámil so súčasnou západnou sociológiou prostredníctvom výberovej prednášky na túto tému.

Zdá sa však, že v čase svojej prvej návštevy Sovietskeho zväzu Mills zjavne vyšiel za rámec prideleného mu obrazu. A hoci bol vítaný v ZSSR ako „hlavný kritik americkej

2 Momdžjan Chačik Nišanovič (1909-1996) - profesor MŠU, významný odborník v oblasti sociálnej filozofie a dejín filozofie. 
spoločnosti“ (Ritzer, 1988, s. 60), nezdržal sa vraj kritických poznámok aní na adresu ZSSR. Tak, počas slávnostného stretnutia na jeho počest’ v Moskve, Mills využil príležitost’ aby zaútočil na cenzúru v Sovietskom zväze, a to v podobe prípitku „na tie dni, ked’v Sovietskom zväze budú uverejnené všetky diela Leona Trotského“ (tamže). O mnoho rokov neskôr sa túto epizódu rozhodol pripomenút už ruský autor A. M. Nikulin. Upresnil pritom, že sa odohrala na Ústave filozofie Akadémie vied počas recepcie na počest̉ Millsa, a že ten sa vo svojom prípitku vraj dožadoval „plnej rehabilitácie súdruha Trockého na znak ustanovenia politickej slobody v ZSSR“ (Nikulin, 2003, s. 175). Musíme však brat’ na vieru tieto tvrdenia autora, lebo zdroj, na ktorý sa odvoláva, tieto údaje nevykazuje. Ide o knihu, obsahujúcu listy a autobiografické spisy Millsa, ktorú v roku 2000 vydali jeho dcéry (Mills, 2000). Z nej sa dozvedáme o mnohých dovtedy malo známych faktoch osobného a profesiového života Millsa. Práve z tejto knihy som sa dozvedela, že jeho prvá návšteva Sovietskeho zväzu sa uskutočnila na pozvanie moskovského vydavatela ruskej verzie Mocenskej elity (Mills, 2000, s. 289). Avšak o údajnom prípitku v knihe nie je žiadna zmienka. Za seba môžem povedat' len to, že som o tejto epizóde nikdy nepočula, ani vtedy, ani neskôr. V každom prípade sa zdá, že sa z nej nestala udalost', ktorá by vážne ohrozila už rozbehnuté vztahy medzi sovietskymi sociológmi a Millsom. Mohla len poukázat’ na ich zložitost’ a nejednoznačnost', čo som vytušila už z rozhovoru s Momdžjanom.

Ten rozhovor z roku 1960 určitým spôsobom uzavrel cyklus významných pre mňa epizód, súvisiacich s Millsom a jeho Sociologickou imagináciou. Ani vo svojom súhrne neprerástli do nejakej významnej udalosti pre môj profesiový život, ale predsa zanechali vo mne raz navždy predstavu o Millsovej ludskej a odbornej výnimočnosti, ktorá mi neskôr pomohla zúčastnit’ sa procesu ovela účinnejšieho osvojovania Millsa, len už na slovenskej pôde. Ale o tom trochu neskôr.

Vrátme sa však ešte k obdobiu 60. rokov v ZSSR, ktoré boli mimoriadne dôležitými nielen pre recepciu Millsovej tvorby sovietskou sociológiou, ale aj pre jej svojráznu asimiláciu. A hoci rozhovor s Momdžjanom prezradil istú rozpačitosṫ vo vztahu k Millsovi zo strany zarytých „histmatčikov“, zavedenie Millsovej tvorby do „vedeckého obehu“ pokračovalo aj v 60. rokoch, dokonca aj po jeho náhlom úmrtí v marci 1962. Zdalo sa, že vo vztahu k nemu všetko ostalo po starom a že domáci autori ho stále vnímajú ako „priatela v zbrani“, ako nelútostného kritika americkej kapitalistickej spoločnosti, na ktorého sa dá spolahnút'.

Preto aj po desatročiach, ktoré uplynuli od tých čias, dost’ zaráža celkom odlišný pohlad na „prípad Millsa“, s ktorým sa stretávame už v postsovietskom období. Tak, podla Nikulina „sovietski ideológovia vedeli operatívne využit’ jeho kritiku západnej spoločnosti tým, že uverejnili Mocenskú elitu“ (Nikulin, 2003, s. 166). Ale, že „po smrti Millsa o ňom spomínali v ZSSR nie často, a to len občas prekladajúc a prepisujúc stručné úryvky z jeho prác“ (tamže). A to vraj preto, že hoci Mills bol dvakrát pozývaný do Sovietskeho zväzu, mal údajne mnoho kritických poznámok aj na adresu komunistického Ruska. Autor síce nehovorí priamo o zhoršení vzt’ahu k Millsovi v ZSSR, ale zrejme si to mysli. A zrejme pripisuje tomu vinu za oneskorenie ruského vydania Sociologickej imaginácie.

I ked' sa daná verzia príčin úpadku Millsovej popularity v ZSSR môže zdat' niekomu presvedčivou, je dost’ ukrátená o dôležité podrobnosti tohto príbehu. Autor si môže dovolit' ich opomenút', ked’ má pred sebou retrospektívu štyroch desatročí recepcie Millsa. Môže si dovolit aj istý schematizmus postsovietskych naratívov, ktoré sa nezaobídu bez 
povinných „sovietskych ideológov“. Tí sú však asi zbytoční, a stačilo by uviest’ len „stranícke vedenie“. Inak by to vyzeralo tak, že otázky akvizície a nasledovnej edície v ruštine vhodnej zahraničnej literatúry by musel riešit nebodaj samotný M. A. Suslov, ktorý bol dlhý čas tajomníkom UV KSSS pre ideologické otázky. V skutočnosti výber takých perspektívnych zahraničných autorov ako Mills, ktorí by sa dali uplatnit pre edičné a propagačné ciele, často závisel od bežných knižničných pracovníkov, ktorí dlhodobo sledovali tvorbu prominentných západných filozofov, sociológov, publicistov a zhromaždovali ich bio-bibliografické údaje. Práve oni zabezpečovali informačnú základňu v oblasti spoločenských vied pre akademických pracovníkov všetkých stupňov, vrátane tých vyšších. Nemôžeme však presne povedat, kedy a kde padalo „pragmatické“ rozhodnutie „ideológov“ o vzostupe alebo páde toho-ktorého autora, ale je iste, že to bolo výsledkom pôsobenia ovela zložitejšieho súboru faktorov, než ten, ktorý opisuje autor.

V tomto zmysle ovela bližšie k ich odhadu je L. A. Kozlovová, ktorá vysvetluje niekdajší záujem sovietskeho obecenstva o Millsa tým, že jeho „protikapitalistické zameranie a propagandistický duch jeho prác, ako aj jeho naklonenost’ k sociologickému učeniu K. Marxa zodpovedali ruskému politicko-ideologickému ovzdušiu 50.-60. rokov“ (Kozlovová, 1995, s. 165). Akonáhle však v Rusku došlo k politickým zmenám, „vlna záujmu o sociologické dedičstvo Millsa opadla" (tamže).

V 60. rokoch však vlna záujmu o Millsa bola ešte na patričnej úrovni. Prejavovalo sa to predovšetkým frekvenciou jeho citovania domácimi autormi, ktorá sa v tejto dekáde nielen neznížila, ale určite aj stúpla. Bolo to totiž „úrodné“ obdobie pre obnovujúcu sa sovietsku sociológiu, ktorá sa po absolvovaní v 50. rokoch fázy svojho uznania ako vedeckej disciplíny, teraz už blížila k svojej inštitucionalizácii. A tak zasiate v 50. rokoch semienka sociologických bádatel’ských iniciatív sa v 60. rokoch vracali solídnymi monografiami a kolektívnymi zborníkmi. Skoro v každej z týchto publikácii nájdeme citácie z diel mnohých domácich a zahraničných autorov, a medzi nimi aj Millsa.

V tom vlastne aj spočívala „recepcia“ jeho diel v ZSSR, ktorá by sotva bola možná, nebyt v jej pozadí „pomalého a opatrného procesu rehabilitácie sociológie“ (Firsov, 2001, s. 17), ktorý sa roztiahol na celých 15 rokov (1953-1968). Roky obrodenia sovietskej sociológie sa prekrývali s najúspešnejšími rokmi pre Millsa ako autora niekol'kých sociologických bestsellerov, oboznámenie s ktorými sa stalo nielen podnetným, a dokonca aj profesionálne potrebným pre nových adeptov sociologickej vedy v ZSSR. Ved' bez osvojovania dedičstva klasickej a súčasnej západnej sociológie, a teda bez recepcie diel takých sociológov ako C. W. Mills, R. Merton, P. Lazarsfeld, T. Parsons, nebolo by možne ani obnovovanie sociológie v ZSSR. Zároveň aj tá formujúca sa sovietska sociológia nutne potrebovala mat’ pevné inštitucionálne zázemie, aby mohla zabezpečit vhodný organizačný rámec pre realizáciu plnohodnotných kontaktov s predstavitelmi západnej sociológie. Inštitucionalizácia sociológie by pomohla otvorit’ viac priestoru pre prekladanie a vydanie dôležitej sociologickej literatúry, s ktorou sme sa vtedy zoznamovali v „lepšom“ prípade vd’aka recenzovaniu a referovaniu, a v horšom, prostredníctvom jej príležitostného citovania renomovanými autormi.

$\mathrm{V}$ „horšom“ preto, že citovanie originálneho textu nejakého zahraničného autora vždy bolo podriadené momentálnemu publikačnému zámeru určitého domáceho autora, ktorému na tom citovaní záležalo. Preto vždy bolo selektívnym a pragmatickým. Z originálneho textu sa vyberali len tie ukážky, ktoré tesne súviseli s obsahom a zameraním 
príspevku domáceho autora. Nebolo ich zatažko vyhladat v prípade rovnakého tematického zamerania obidvoch textov, alebo ich ideovej príbuznosti. A to vtedy, ked'ich autori rovnako bojovne útočili na súčasný kapitalizmus, ako pôvodcu všetkých spoločenských neštastí a nezdarov. Najmä však, ked’ objavovali spoluvinníka, stelesneného nejakým sociologickým smerom, ktorý sa vyznačoval apologetickým vztahom voči buržoáznej spoločnosti. Nie div potom, že ten domáci autor rad čerpal určité fakty a kritické argumenty od takých západných autorov, ktorí sami prichádzali s podnetnou a sústredenou kritikou kapitalizmu a jeho sociologických zástancov. Práve k takým patril C. W. Mills, Mocenská elita ktorého „strháva z buržoáznej demokracie jej klamlivé odevy, odhaluje jej falošný charakter“ (Mills, 1959b, s. 5).

Podobnú úlohu, ale už viac zameranú bezprostredne na západnú sociológiu by mala od určitého času plnit aj Millsova Sociologická imaginácia. Stala sa nielen významným zdrojom faktických informácií, ale aj účinnou kritickou zbraňou, po ktorej radi siahli takí renomovaní autori ako G. V. Osipov, N. V. Novikov, M. Š. Bachitov, G. M. Andrejevová, a í.

$\mathrm{Na}$ začiatku 60. rokov sa niektorí z nich ešte obmedzovali na použitie nejakého výstižného výroku Millsa ako „čerešničky na torte“ alebo „bodky nad i“, aby efektne ukončili svoj vlastný príspevok. Postupne si však skoro všetci uvedomili skutočnú váhu tak Millsovej osobnosti, ako aj jeho sociologického diela, odvolávanie sa na ktoré zaručovalo „značku kvality“ ich vlastným publikáciám. To určite prispelo k zvýšeniu indexu citovania vlastných Millsovych prác v sociologickej literatúre, vydanej v ZSSR v priebehu 60. rokov. Bolo však vidiet', že Mocenská elita pomaly ustupuje svoje miesto Sociologickej imaginácii, záujem o ktorú sa u bežných čitatelov ešte nenasýtil. Tí z nich, ktorí sa z istých dôvodov nemohli dostat k originálnemu textu, sa museli uspokojit’ s tými omrvinkami pretlmočeného Millsovho textu, ktoré im „spadli zo stola“ odborníkov. Títo sa však pritom riadili svojimi momentálnymi praktickými záujmami, vyplývajúcimi z charakteru ich vlastných autorských úloh. V tomto ohlade dochádzalo aj k svojráznej „del'be práce“ medzi rôznymi autormi. Taký známy autor ako M. Š. Bachitov, čo sa venoval kritike štrukturálneho funkcionalizmu Parsonsa (Bachitov, 1965), povyberal zo Sociologickej imaginácie len tie pasáže, ktoré boli venované kritike „Vel'kej teórie“, aby ich použitím posilnil vlastnú ofenzívu proti Parsonsovi. Využíva tu Millsa doslova ako spolubojovníka, ale v dost' zúženom zábere. Nepotrebuje pripomínat iné témy tejto knihy, ktoré by inak mohli byt dôležité z hladiska perspektív vývoja sociológie ako takej. Autor však tieto témy starostlivo obchádza.

V prípade, že by sa autor publikácie špecializoval na sociologickú metodológiu, ako napríklad G. M. Andrejevová (Andrejeva, 1965), ktorá čítala Sociologickú imagináciu už v roku 1959, bolo by možné očakávat’ patričný záujem o kapitolu „Abstraktný empiricizmus“. Bolo to tak, lenže autorka dala prednost’ podrobnému výkladu Millsovej interpretácie problému sociologického empirizmu pred príležitostným citovaním jeho jednotlivých výrokov. V niečom s nim súhlasí, v niečom nie. Pre ňu sa Mills stáva nielen eventuálnym kolegom, autorom kritických poznámok na adresu Lazarsfelda, ktorého ona sama dobre preštudovala, ale skúseným a inšpiratívnym partnerom, ktorý naučí ako obíst’ „Metodologický zákaz“ alebo sa vyhnút” „Rituálu štatistiky“. Využíva však aj obsah kapitoly „Vel'ká teória“, ked’ robí samostatný a náročný rozbor Parsonsovej koncepcie sociologickej teórie. V tejto súvislosti poukázala na niektoré nosné Millsove myšlienky, 
ale tiež nie vo všetkom s nim súhlasila. Využila však príležitost’ vyrozprávat’ neinformovanému čitatelovi obsah dvoch nosných kapitol Sociologickej imaginácie. Na rozdiel od iných autorov, ktorí citovali Millsa, Andrejevová neváha vyjadrit’ sa k Millsom otvorenej téme byrokratizácie sociológie. Podporuje aj niektoré iné myšlienky autora Sociologickej imaginácie, ktoré sa týkali nazerania sociológa na spoločnost’.

Toto želanie autorky priniest' čitatelovi z obsahu Sociologickej imaginácie to najcennejšie, a to šest' rokov po jej vydaní, nemôže nevyvolat obdiv. Takisto ako pripomínanie v texte Millsa ako pokrokového sociológa. Tento titul si vyslúžil postupne, až po tom, čo nejaký čas mal „hodnost“ liberálno-buržoázneho sociológa, ktorú mu pridelili v predslove k ruskej verzii Mocenskej elity (Mills, 1959b, s. 4). Teraz však Millsa najprv zaradili medzi „pokrokovo naladených filozofov, sociológov a ekonómov“, aby potom znova potvrdili, že patrí medzi „progresívnych sociológov“ (Modržinskaja, 1962, s. 36-37), a to za jeho knihy Mocenská elita, Príčiny tretej svetovej vojny, Počúvajte, Yankee: revolúcia na Kube. Význam tohto zaradenia sotva možno podcenit, ked' zoberieme do úvahy, že ich autorkou bola vedúca sektora súčasnej buržoáznej filozofie a sociológie západných krajín Ústavu filozofie AV ZSSR Je. D. Modržinskaja, ktorá sa sama špecializovala na kritiku antikomunizmu. Zaradenie zahraničného autora do kategórie pokrokových sociológov bolo v tých časoch vel'mi dôležite nielen pre neho, ale aj pre tých domácich autorov, ktorí ho citovali. Získavali tým pádom akúsi licenciu na bezpečné citovanie a komentovanie jeho diel, dokonca na prípravu špeciálne jemu venovaných referátov a štúdií. Neprešiel však ani rok, ako sama Modržinskaja uverejnila v časopise Voprosy filosofii špeciálnu stat' o Millsovi s príznačným názvom „Pokrokový jav v súčasnej americkej sociológii“ (Modržinskaja, 1963). Bolo to už po jeho nečakanom úmrtí. Ako vidiet’ z názvu, Mills tak aj ostal do konca pre svojich komentátorov akýmsi výnimočným javom. Ved’ za „svojrázny a mimoriadny jav v súčasnej americkej buržoáznej literatúre“ bola svojho času označená i Mocenská elita (Mills, 1959b, s. 5). Neupieralo sa mu však právo, teraz už oficiálne, prostredníctvom uznávaného časopisu dostat’ sa do kategórie „pokrokových vedcov“. Autorka dostatočne zdôvodnila toto zaradenie Millsa, ked' vyzdvihla v jeho diele prevažne tie aspekty, ktoré rezonovali s blízkou jej tematikou boja proti antikomunizmu. Zdôrazňuje Millsovu kritiku protidemokratických praktík imperialistického štátu, poukazuje na to ako on vystupoval proti vytváraniu ilúzií ohladom ludového kapitalizmu alebo sociálnej harmónie. Tieto Millsove aktivity boli postačujúce na to, aby ho vyhlásila za pokrokového sociológa.

Prívlastok pokrokový sa však zdá byt’ natol'ko neurčitý a pružný, že doň možno vložit’ hocijaký obsah. V danom prípade sa zdal byt výsledkom určitého kompromisu medzi želaním zapísat' Millsa do svojho marxistického tábora a objektívnou nemožnostou toto urobit. Tento pojem by potreboval aspoň upresnenie, či naozaj súvisí s pojmom pokroku a či sa môže pridelovat' lud’om, ktorí sa o ten pokrok, teda technický, spoločenský, či historický zaslúžili? A či to nebola náhrada za označenie „marxistický sociológ“, ktoré sa na Millsa nedalo uplatnit? Tak či onak, ale prívlastok pokrokového sociológa na nejaký čas prirástol k Millsovi, stal sa jeho vizitkou a značne zvýšil jeho citačný index. S týmto prívlastkom bol uvedený na stránkach nielen knihy G. M. Andrejevovej, ale aj v knihách a štúdiách G. V. Osipova, N. V. Novikova a iných renomovaných sovietskych sociológov. V polovici 60. rokov záujem o Millsa doslova vrcholí, svedectvom čoho sú články, ktoré sa špeciálne venujú Millsovi a jeho miestu v súčasnej západnej sociológii. Medzi nimi treba osobitne vyzdvihnút’ analytickú štúdiu od L. A. Cypnikovej (Cypnik, 1964), v ktorej po- 
dáva prvý v domácej odbornej literatúre celistvý výklad Sociologickej imaginácie. Týmto spôsobom autorka poskytla širšej verejnosti viac-menej komplexný pohlad na toto dielo, známe doteraz len zopár odborníkom. V roku 1966, časopis Voprosy filosofii na počest’ Millsovho nedožitého polstoročného jubilea pripravil a zverejnil v čísle 6/1966 celý výber štúdií pod spoločným názvom Charles W. Mills a úloha sociológa v spoločnosti, čím značne prispel k hlbšiemu poznaniu a popularizácii Millsovej tvorby. V tomto období totiž mimoriadne vzrástol dopyt po podrobných a kvalifikovaných informáciách o západnej sociológii. Vznikla ostrá potreba v odborných kádroch pre sociológiu. Tí pracovníci, ktorí prichádzali do tejto disciplíny z rôznych iných odborov si však uvedomovali „nedostatok profesionálnych vedomostí a kontaktov so zahraničnou vedou“ (Firsov, 2001, s. 37). Aj z tohto hladiska sa sociológia potrebovala inštitucionalizovat', čo bolo jasné mnohým, dokonca aj najvyššiemu straníckemu vedeniu (Firsov, 2001, s. 26).

Mne však už nebolo súdene sledovat zblízka túto nadchádzajúcu inštitucionalizaciu sociológie v ZSSR. Musela som sa z rodinných dôvodov v roku 1965 prestahovat’ do Bratislavy. Tam sa mi podarilo v októbri tohto roku nastúpit na katedru sociológie Filozofickej fakulty Univerzity Komenského v Bratislave. Odvtedy som mohla sledovat procesy inštitucionalizácie a dalšieho vývoja sociológie v ZSSR, ako aj proces recepcie Millsa, už z určitého odstupu.

Z tejto pozície som sa potešila predovšetkým zavŕšeniu procesu inštitucionalizácie sovietskej sociológie, a to založením v roku 1968 Ústavu konkrétnych sociálnych výskumov AV ZSSR. Ten sa neskôr premenoval na Ústav sociologických výskumov, aby napokon získal názov Ústavu sociológie Ruskej akadémie vied. Bola som vel’mi rada aj tomu, že sa na filozofickej fakulte Moskovskej univerzity v tom istom roku otvorila katedra metodiky konkrétnych sociálnych výskumov (MKSV), na čele ktorej stála moja niekdajšia učitelka a školitel'ka prof. G. M. Andrejevová, ktorá ma vlastne aj priviedla ku štúdiu západnej sociológie.

Dokonca aj v prípade recepcie Millsa som mohla i napriek vzdialenosti od Moskvy zaznamenat' významný príspevok v podobe prvej sovietskej monografie o Millsovi, ktorú vydal v roku 1977 V. F. Korovin. Tú mi poslal kolega z filozofickej fakulty Moskovskej štátnej univerzity (MŠU). Autor, tiež pracovník tejto fakulty, podáva vo svojej knihe všestrannú charakteristiku Millsovho diela, pričom rovnakú pozornost’ venuje tak problémom sociálnej štruktúry, mocenskej elity, amerického militarizmu, ako aj sociologickej imaginácii a novej sociológii. Poukazuje na pozitívne stránky sociológie Millsa, ale popritom v rade otázok s nim nesúhlasí a hladá príčiny jeho omylov. A hoci autor učil na filozofickej fakulte MŠU, sotva asi mohol prednášat o Millsovej sociológii študentom katedry MKSV. Tvorba C. W. Millsa si akosi nenašla miesto vo vtedajších akademických prehladoch dejín buržoáznej sociológie dvadsiateho storočia. Ked’ sa raz v jednom z nich objavilo jeho meno (Jonin \& Osipov, 1979, s. 75), tak to bolo v súvislosti s radikálnym smerom v americkej sociológii, ktorý vraj rozvíjal jeho idey. Aby mohol Mills aj po svojej smrti znova budit záujem verejnosti, bolo treba aktualizovat jeho politický a sociologický radikalizmus, ktorý sa osobitne zvýraznil počas jeho hladania kontaktov s hnutím Novej lavice v Anglicku. Stal sa dôležitým východiskom pre formovanie nového obrazu Millsa ako lavicovo-radikálneho sociológa, ktorý celkom vytlačil jeho niekdajší imidž liberálneho amerického profesora, ako aj podobu pokrokového sociológa zo sovietskych čias. V 90. rokoch sa Mills uvádza v ruských encyklopedických vydaniach nie inak, ako lavico- 
vo-radikálny sociológ, ideológ Novej l’avice a zakladatel” „novej sociológie“, ktorú niektorí historici sociológie retrospektívne zasadzujú do obdobia 50.-60. rokov ako riadny sociologický smer, ktorý akoby pôsobil už vtedy. Prihlásenie k Novej lavici dodalo Millsovej sociológii už po jeho smrti druhý dych a prinieslo jej novú popularitu. Čo sa týka „novej sociológie“, ako sociológie „velkého dosahu“ (big-range), tá nastoluje perspektívu tvorby „verejnej sociológie - prístupnej kontrole, vystavenej kritike, tužiacej po zlepšení" (Horowitz, 1965, s. 19). Táto perspektíva sa ukázala dostatočne nosnou, ked’ si spomenieme na koncepciu verejnej sociológie od bývalého prezidenta ISA M. Burawoya.

To sme teda dost' odbočili od obdobia 60. rokov, ked’ sa pôvodná recepcia Millsa v ZSSR zavŕšila všestrannou reflexiou jeho pôsobenia v úlohe pokrokového sociológa. A práve v polovici 60 . rokov sa mi naskytla príležitost’ sledovat’ paralelne prebiehajúcu recepciu Millsovej tvorby, ale už na Slovensku, ktoré vtedy tvorilo súčast' Československa. Priebeh tejto recepcie dost’ pripomínal analogický proces v Sovietskom zväze. Tiež sa začínala pôvodným neskrývaným záujmom o jednotlivé Millsove diela, pokračovala ich hojným citovaním a referovaním, kým sa nezastavila pri obšírnejších a všestrannejších prehladoch jeho celkovej tvorby. Vynikajúcim príkladom takého analytického prehladu Millsovho diela bola kapitola pod názvom „C. Wright Mills čiže ideál angažovanej sociológie“, ktorá tvorila súčast' Vízií ludského sveta (1967) od Zygmunta Baumana.

Bol to síce vynikajúci, ale predsa komentár. Záležalo však na uverejnení Millsovej originálnej tvorby, nech aj v podobe prekladov, a tú už nezáležalo či slovenských, alebo českých. Ved’ Slovensko v tom čase spolunažívalo s Českom v rámci jedného štátu. A slovenskí odborníci v oblasti spoločenských vied tesne spolupracovali so svojimi českými kolegami. Jednou z výhod tejto spolupráce bolo spoločné využitie knižnej produkcie, ktorá sa vydávala v každej krajine. Z tohto hladiska treba ocenit činnost' českých vydavatel'stiev Orbis a Mladá fronta, ktoré sa zaslúžili o vydanie prekladov dvoch vrcholných Millsovych diel, a to Mocenskej elity (1966) a Sociologickej imaginácie (1968).

V tomto teda československí vydavatelia „predbehli“ kolegov zo ZSSR, kde ako vieme bola v tom čase preložená len Mocenská elita. Preto aj aplikácia termínu recepcia na proces zavedenia Millsa na Slovensko bola viac opodstatnená ako v prípade podobného procesu v Sovietskom zväze. Už od 50. rokov sa tieto vydavatel'stvá usilovali o systematický prísun na knižný trh jedinečných sociologických vydaní z domácej a zahraničnej tvorby. Tým prispeli $\mathrm{k}$ budovaniu poznatkovej základne $\mathrm{z}$ oblasti sociológie tak u odborníkov, ako aj u širšieho obecenstva. V období 50.-60. rokov to bolo nesmierne dôležité na prípravu vhodnej pôdy pre recepciu tejto zabudnutej disciplíny. Však aj v Československu, ako aj v iných socialistických krajinách prebiehal vtedy proces obnovenia sociológie, ktorý v 60. rokoch podobne ako aj v ZSSR vyústil do jej inštitucionalizácie. Jej reálnym výsledkom bolo založenie v roku 1964 katedry sociológie na Filozofickej fakulte Univerzity Komenského v Bratislave. Tam som získala vzácnu príležitost' vyučovat dejiny sociológie a súčasné sociologické teórie, teda predmety, ktoré nám na škole neprednášali ani v rámci dejín filozofie.

V roku 1965 katedra zahájila riadnu výuku sociológie, a už za nejaký čas na rad prišiel aj kurz Súčasne sociologické teórie, v rámci ktorého sa vyskytoval seminár na tému „C. Wright Mills a inštitucionálna škola“. Samotný Mills sa k takejto škole nehlásil, hoci stále prízvukoval vztah medzi človekom a inštitúciou. Pre Z. Baumana to bol dostatočný dôvod pre to, aby vo svojej Sociológii zaradil Millsa do tejto školy, a mne sa to zdalo 
dost' logickým. Preto aj na seminári sme najprv sa venovali všeobecnej charakteristike inštitucionálnej školy, aby potom prejst’ k napísanému Millsom spolu s H. Gerthom Charakteru a sociálnej štruktúre. Vel'kú pozornost’ sme však venovali Mocenskej elite, ktorá k tomu času už bola preložená. A hoci bolo možné nájst’ k nej určitý komentár v Soudobej sociológii od J. Klofáča a V. Tlustého, orientovala som študentov na čítanie pôvodného Millsovho textu. Malo to úplne iný efekt, a sotva nejaká iná udalost’ mohla vtedy konkurovat’ nášmu obyčajnému semináru, kde sa analyzovala štruktúra súčasnej americkej spoločnosti, alebo sa rozoberali také chýrne Millsove pojmy ako „biele goliere“ a „mocenská elita“.

Ako mi, spomínajúc na to obdobie, píše bývalý absolvent našej katedry prof. PhDr. Juraj Schenk, CSc., ktorý študoval v školských rokoch 1966-71: „Mills bol vtedy oficiálne vel’mi populárny a niekedy v tom období (ale zrejme neskôr) vyšla v češtine aj jeho Sociologická imaginácia. Mocenská elita vtedy aj medzi študentmi vyvolávala jasné paralely s našimi vtedajšími podmienkami (nomenklatúra atd') a pomerne rýchlo sa na ňu (po r. 1968) radšej ,zabudlo. Pamätám si, že Mills bol populárny aj ako l’enfant terrible a kdesi kolovala jeho fotografia na vel'kej motorke (Harley Davidson?), v kockovanej košeli a bagančiach - jednoducho, nebol to sociológ v obleku!“

Obsah svojich vtedajších študentských poznámok („je ich kopa!“) z dvoch seminárov o Millsovi, ktoré odzneli v novembri 1967, Juraj Schenk zhrnul do niekolkých bodov:

- „Sociologická imaginácia - základné metodologické problémy, súlad i rozpor s ostatnými empirickými a teoretickými prístupmi,

- kritika z pozícií rozhnevaného liberalizmu, neoindividualizmus, konfrontácia s Jeffersonovým ideálom starých stredných tried, nadväznost’ na Marxa a Webera,

- rozdiely Marx - Mills,

- pochopenie sociálnej štruktúry len v historickom vývoji a konkrétnej historickej situácii, Mills neporovnáva rozličné soc. štruktúry - len USA,

- pluralita inštitúcií a ich formatívny vplyv na skupiny i osobnost'.

Mám dojem (a môže byt’ nesprávny), že imaginácia bola v tom čase asi skôr len doplnkovou problematikou, lebo sa k tomu ešte nedalo nič čítat."

Dojem bol teda správny, o Sociologickej imaginácii sa vtedy naozaj na seminári nehovorilo, lebo jej preklad sa objavil o rok neskôr. Ale ostatne témy, ktoré odzneli na seminári, autor reprodukoval v plnom počte. Podal verný obraz toho, ako študenti v tom čase vnímali materiál, ktorý sa im ponúkal tak v podobe prístupných vtedy Millsovych diel, ako aj v komentároch učitela.

Už to, že účastník seminára, ktorý sa odohral v novembri 1967, zachoval po vyše polstoročí také živé spomienky na jeho obsah, hovorí predovšetkým o tom, aký význam mal Mills pre vtedajšiu sociologickú mládež. Aj na tomto príklade sa ukazuje, že vtedajšie zaradenie Millsa do učebných programov katedry sociológie bolo najlepším spôsobom, ako zakotvit jeho idey v povedomí sociologickej verejnosti, ktorú vtedy predstavovali študenti sociológie. Čo by ešte mohlo viac ovplyvnit povedomie mladých adeptov sociológie, ako nie systematický a fundovaný proces učenia novým, neznámym a zvodným ideám, ktorými boli preplnené prístupné im vtedy Millsove diela. Ktorý nástroj pre recepciu týchto už zverejnených diel bol by v tých podmienkach účinnejším?

V tom asi aj spočívala hlavná odlišnost’ recepcie Millsa na Slovensku od recepcie Millsa v ZSSR. Na Slovensku sa o Millsovi prednášalo na vysokej škole, medzitým, čo v ZSSR 
k tomu nedošlo ani v 60. rokoch, ani neskôr, hoci pre to už boli podmienky. Preto aj recepcia Millsovej tvorby na Slovensku našla pevné zázemie v podobe univerzitného kurzu, ktorý sa opakoval rok čo rok, pre každý nový študentský ročník.

Rozdiel bol aj v mojom vnímaní obidvoch procesov recepcie. Recepciu na Slovensku sa už nedalo zobrazit ako malú sériu náhodných epizód z môjho života, ktoré by súviseli s Millsom. Bola to skôr jedná epizóda, ale dížkou 50 rokov. Totiž tak dlho trvalo moje pedagogické pôsobenie na slovenských univerzitách. A skoro všetky tieto roky Millsova postava bola tak či onak vtiahnutá do môjho profesijného života. Avšak na pôde Slovenska sa mi viac darilo vystupovat' v aktívnej úlohe nielen pozorovatel'ky procesu recepcie Millsa a jeho tvorby, ale jej aktívnej účastníčky. Bolo to umožnené mojím postavením vysokoškolskej učitel'ky, ktorá mohla zaradit’ Millsa do učebných programov, mohla o ňom prednášat a viest' jemu venované semináre, mohla navrhovat súvisiace s ním témy ročníkových a diplomových prác, apod. Bol to celkom iný pocit, ked’ sa dalo aktívne vystupovat $\mathrm{v}$ prospech toho, aby Mills dlhšie ostal v pamäti slovenských sociológov.

A čoby sa mohlo najhlbšie vryt’ do tejto pamäte, ako nie Millsova Sociologická imaginácia, český preklad ktorej vyšiel v roku 1968. Hned' potom sa táto kniha dostala do zoznamu povinnej literatúry pre semináre, ktoré boli venované Millsovi. Nielenže obohatila program seminárov o d’alšiu nosnú tému, ale aj značne oživila ich priebeh. Teraz mohli študenti sami čítat d’alšie Millsovo originálne dielo, pripravovat z neho samostatné referáty, diskutovat' o ňom. Nerobili sme k tomu formálne prednášky, ale dali prednost’ živému kontaktu s Millsovou tvorbou, čo sa aj osvedčilo. Študenti začali zháňat Sociologickú imagináciu v kníhkupectvách, požičiavat si ju v knižniciach a prekonávajúc svoju bytostnú nechut' k čítaniu, predsa len sa oboznamovat’ s touto červenou knižočkou. Nepochybujem, že mnohým doteraz ostala v pamäti. Na katedre za pár rokov prepukol svojrázny Millsov „boom“, ked’ ročník 1967-72, kde som bola ročníkovou vedúcou, začal prihlasovat' najprv témy ročníkových, a neskôr aj diplomových prác. Ukázalo sa, že témy, súvisiace s Millsovou tvorbou, boli najatraktívnejšie. A došlo k takému paradoxu, že na Slovensku o Millsovi nepísal nikto okrem akademika Siráckeho a zopár študentov sociológie, ktorí práve obhájili svoje diplomové práce.

Obsah týchto diplomových prác sa prevažne točil okolo výkladu prvých kapitol Sociologickej imaginácie, lebo tie boli najzrozumitel’nejšie, a preto aj prítažlivejšie pre študentov. Oni sa radi sústred’ovali na výklade Millsovej kritiky „Velkkej teórie“ a „Abstraktného empiricizmu“. Však aj semináre v prvých rokoch po tom, čo sa objavila Sociologická imaginácia, boli ladené v tom istom duchu. Vtedy bolo dôležité, aby si študenti osvojili najprv tieto kritické, a preto aj najpopulárnejšie kapitoly Millsovej knihy spolu s tou úvodnou, vysvetlujúcou samotnú ideu sociologickej imaginácie. V podstate aj svetové sociologické spoločenstvo sa vtedy zastavilo pri tomto poznávacom minime, a nejako sa neusilovalo ho rozširovat'.

Mne sa však pri každoročnom čítaní Sociologickej imaginácie, už len z tej pedagogickej priotrávenosti žiadalo rozšírit’ poznávacie obzory, a tak som začala postupne pridávat do programu dalšie kapitoly z tejto knihy. Ich výber bol ovplyvnený mojím vtedajším prístupom k tejto knihe. Ten sa dost’ zmenil od toho roku 1959, ked’ som sa na krátky čas dostala k originálu. Vtedy som ešte nevedela postihnút skutočný význam tejto vzácnej knihy. Bola som vtedy uzavretá do rámca svojich momentálnych úzko-praktických záujmov a preto som pristupovala k obsahu knihy dost' selektívne. V mojom vztahu k nej 
stále prevládalo zdielanie jej kritického zápalu, tak evidentného v prvej polovici knihy, venovanej „deformáciám tradičných tendencií“ sociológie (Mills, 1968, s. 24), ako záujem o tie kapitoly, ktoré sa týkali „perspektív sociálnych vied“ (tamže). Obávam sa, že tak vtedy mohli vnímat obsah Sociologickej imaginácie aj iní moji kolegovia, pre ktorých ona vystupovala ako zbraň v boji s eventuálnym ideologickým nepriatelom.

Až postupne som presmerovala svoju pozornost’ na iné dôležité témy, ktoré sa preberali v tejto knihe. Vtedy som ocenila u Millsa jeho všestrannú a prenikavú, a v svojich záveroch i vel’mi poučnú reflexiu západnej sociológie, ktorú sme dost' dlho označovali za buržoáznu. Neprekážalo nám to však v preberaní mnohých jej poznatkov a postupov. Boli sme však vtedy ešte v rannej fáze toho preberania, medzitým čo autor knihy bol od nás neporovnatelne skúsenejší. Pretavil tieto prácne získané skúsenosti do odzbrojujúcej múdrosti staršieho kolegu, ktorý upozorňuje tých „mladších“ na prípadné nebezpečenstvá a sklamania, čo ich ešte čakajú.

V tomto zmysle Sociologická imaginácia bola podla mňa určená vôbec nie pre začiatočníkov v sociológii s ich naivnou vierou v čistotu a dobré predsavzatia svojej disciplíny. Bola adresovaná zrelým odborníkom, ktorí už prešli vážnymi životnými a profesiovými skúškami. Pre nich idea sociologickej imaginácie, ktorú autor sústavne presadzuje, nie je len formálnou školskou poučkou, ktorej sa dá v nejakej životnej fáze naučit', aby v nejakej d’alšej naň zabudnút. Je to bytostný princíp disciplíny, jej dôležitý atribút. Žial', že mnohé Millsove upozornenia ostávajú nevypočutými mladými adeptmi sociológie. O to istejšie však rezonujú u nich neskôr, po prípadných nezdaroch vo svojej práci a nasledovných pokusoch o ich prekonanie. Vtedy začínajú brat’ obsah Sociologickej imaginácie už nie ako kritickú zbraň, ale skôr ako posolstvo, obrátené ku všetkým sociológom humanistického zamerania. Odvtedy som pochopila túto zvláštnu predurčenost’ Sociologickej imaginácie byt’ súčasne zbraňou ale aj humanistickým posolstvom, adresovaným najmä sociológom. Mali sme možnost' sa k nemu dostat’ na rozdiel od sovietskych kolegov, ktorí sa k bezprostrednému kontaktu s touto knihou v ruskom preklade tak aj nedostali. Tým pádom aj celý proces obrodenia sociologickej disciplíny v ZSSR, ktorý tvoril širší rámec pre reсерсiu Millsa, sa musel zaobíst bez svojej „biblie“. Teda bez knihy, ktorá obsahovala v sebe nielen kritiku západnej sociológie, na čom nám všetkým vtedy prevažne záležalo, ale aj určite predtuchy a varovania pred eventuálnou hrozbou byrokratizácie sociológie.

Mńa práve tieto hrozby podnietili k tomu, aby som doplnila program seminárov o kapitoly, ktoré sa venovali „rôznym formám praxe“ a „byrokratickému étosu“. Hlavne však išlo o záverečný dodatok ku knihe, v ktorom Mills vecne inštruuje čitatel’a o „umení intelektuálnej práce“. Túto jeho prednášku študenti potrebovali asi najviac. Osvojovali však aj kriticizmus Millsa, obrátený do vlastných sociologických radov.

Teraz sa to vidí tak, že už koncom 60. rokov na katedre sociológie Filozofickej fakulty Univerzity Komenského odštartoval postupný, nenápadný, ale účinný proces recepcie Millsovej sociologickej koncepcie. Zúčastňovali sa ho učitelia ako sprostredkovatelia jej myšlienkového obsahu. Hlavnými účastníkmi však boli predsa študenti, ktorí, ako je vidiet’ na príklade prof. Schenka, boli vd’ǎnými recipientami všetkých možných sociologických poznatkov. Teraz, po uplynutí mnohých desatročí sa dá tvrdit', že vd’aka niekdajšiemu záujmu voči takým osobnostiam ako Parsons, Merton, Lazarsfeld, Mills, Dahrendorf, Adorno, Giddens, na Slovensku sa budovala sociologická kultúra, ktorá sa usilovala o svetový formát, a v niečom možno ho aj dosiahla. Teraz záleží na tom ju 
udržiavat a všestranne o ňu sa starat. Tú sú na mieste aj každodenná rutina, aj výbuchy nadšenia, aj prípadne „renesancie“ a „recepcie“ polozabudnutých alebo občas sa vynárajúcich sociologických géniov. Však nedávno nám to pripomenuli podujatím $\mathrm{k}$ jubileu Simmela a vydaním jeho Rembrandta. Za chvílu príde na rad Max Weber...

Spomenieme však teraz na jedného z hlavných účastníkov recepcie Millsa na Slovensku, a to na akademika Andreja Siráckeho. Bol to on, ktorý prvé roky prednášal na katedre o Millsovi, medzitým čo som viedla o ňom semináre. On však ako skoro jediný medzi slovenskými autormi o Millsovi aj písal, pričom opierajúc sa nie o komentujúcu literatúru, ale o originálne Millsove diela, a to ešte pred tým ako sa niektoré z nich objavili v českých prekladoch. Preukazuje pritom dobrú znalost' nielen hlavných Millsovych diel, ale aj tých menej známych. Zoširoka sa vyjadruje skoro ku všetkým hlavným témam Millsovej tvorby, počnúc „strednou triedou“, „bielymi goliermi“, „mocenskou elitou“, a končiac „sociologickou imagináciou“. Analyzuje všetky tieto pojmy vo svojej knihe Sociológia (1966), ktorá nám dlho slúžila pre študijné účely ako skoro jediný slovenský zdroj. Osobitnú pozornost’ v tejto knihe Sirácky venuje problematike sociálnej štruktúry. Zaujíma ho možnost’ využitia marxistického modelu sociálnych skupín a tried „pre analýzu socialistickej a súčasnej kapitalistickej spoločnosti“ (Sirácky, 1966, s. 87). A práve v súvislosti s analýzou poslednej sa autor obracia k názorom „pokrokového amerického sociológa C. Wrighta Millsa“ (Sirácky, 1966, s. 90). Je vel'mi zaujímavo sledovat, ako sa Sirácky doslova inšpiruje Millsovou analýzou „strednej triedy“, ktorú Mills podáva v svojej knihe Biely golier. Sirácky neodmieta tento pojem, ako aj Millsov výraz „biely golier“, ktoré inak narušujú ustálenú predstavu o triednej štruktúre kapitalistickej spoločnosti, tvorenú len dvomi základnými triedami: buržoáziou a proletariátom. Naopak, pokúša sa dat' marxistické vysvetlenie vzniku tejto novej sociálnej skupiny v štruktúre vyspelých kapitalistických štátov na čele s USA v dôsledku tých vážnych zmien, ktoré tam prebehli v predchádzajúcich desatročiach. Opiera sa pritom o Millsove objasnenie týchto zmien ako prejavov „sociálnej nivelizácie“. Išlo teda o tendenciu „po vyrovnávaní príjmov, stieraní rozdielov v životnej úrovni a v postupnom rušení hraníc medzi sociálnymi skupinami“ (tamže). Sirácky dokonca robí z toho dost’ odvážny záver o tom, že aj „V socializme sa utvára nová štruktúra sociálnych skupín $v$ smere vyrovnávania záujmov skupinových so záujmami celospoločenskými a že naša spoločnost’ prestáva už byt triednou“ (Sirácky, 1966, s. 98). Spomínam si, že Sirácky v tom čase práve odsudzoval rovnostárstvo, ktoré sa prejavovalo pri odmeňovaní pracovníkov rôznej vzdelanostnej úrovne. Preto asi považoval za potrebné urobit dôkladné sociologické výskumy zmien a vývojových tendencií v sociálnej štruktúre ČSSR, porovnat ich s podobnými výskumami v iných socialistických krajinách a vypracovat na tomto základe „marxistický model sociálnej štruktúry socializmu“ (tamže). V tomto zmysle tak pre neho Mills vystupuje ako „priatel' v zbrani“, ktorý dodáva marxistickým autorom patričné faktické a číselné údaje o spomínaných trendoch v USA, a tým ich podnecuje $\mathrm{k}$ tomu, aby nanovo preskúmali niektoré tradičné pohlady a vyvodili z toho tak akademické ako aj praktické závery. Nie náhodou tak Sirácky označuje Millsa za pokrokového sociológa. V tom akoby opakoval sovietskych kolegov, produkciu ktorých v podobe publikovaných monografií a časopiseckých štúdií sústavne sledoval. A hoci odkaz na stat’ Modržinskej o Millsovi ako „pokrokovom jave v súčasnej americkej sociológii“ sme v knihe Siráckeho nenašli, predsa ju mohol prečítat'. Napokon označenie Millsa za „pokrokového sociológa“ použili vo svojej knihe Soudobá sociologie známi českí 
autori J. Klofáč a V. Tlustý. Mne sa však použitie tohto označenia bez uvedenia presných kritérií „pokrokovosti“ u A. Siráckeho nepozdávalo, presne tak, ako sa predtým nezapáčilo u Modržinskej. Z kontextu, v ktorom sa používalo toto označenie však bolo možné vytušit', že pod pokrokovostou bola myslená blízost’ k marxizmu. Tak na str. 74 svojej knihy Sirácky najprv naznačuje, že Mills ako i Erich Fromm „vo svojej tvorbe sa dostali blízko k marxizmu“ (Sirácky, 1966, s. 74). O niekol'ko riadkov nižšie ovel’a istejšie tvrdí o Millsovi, že ten „V posledných rokoch života dospel k marxizmu“ (tamže). Lenže robí to pomerne nesmelo a vo svojej knihe často umiestňuje Millsa do „zoskupení“ zmiešanej povahy, kde sociológovia marxistickej orientácie susedia so zjavnými nemarxistami. Jeden taký súbor Sirácky zostavil z vedecky významných západných sociológov, takých ako C. W. Mills, R. Merton, J. Lewis, R. Dahrendorf, R. König, G. Gurvitch, E. Fromm, T. Parsons (tamže). Na str. 76 autor predstavuje tú istú zostavu, doplnenú o Ch. Loomisa a H. Marcuseho. Teraz už títo sociológovia zastupujú „nemarxistické smery, teórie a prúdy“ (Sirácky, 1966, s. 76). Napriek tomu „prinášajú ostrú kritiku spoločenského vývoja v kapitalizme“ (Sirácky, 1966, s. 77), čo treba z marxistického hladiska hodnotit pozitívne. Pričom v radoch kritikov sa kupodivu ocitol aj kritizovaný Millsom Talcott Parsons, ktorého Sirácky o pät rokov neskôr začne napádat za to, že je „nesmierne vzdialený marxizmu a sociológii progresívne angažovanej“ (Sirácky, 1971, s. 16). Píše to vo svojej štúdii „C. Wright Mills a angažovaná sociológia“, ktorá bola uverejnená v prvom čísle českého Sociologického časopisu za rok 1971. V tejto štúdii sa stáva rozhodným obhajcom „,angažovanej sociológie“ Millsa, ktorú dáva do protikladu k „normatívnej“ sociológii Parsonsa (Sirácky, 1971, s. 16). Mimochodom pojem „angažovanej sociológie“ v súvislosti s Millsom ovela skôr použil Z. Bauman.

Podla Siráckeho dnešná sociológia holdovala kultu Talcotta Parsonsa, a pritom „takmer úplne ignorovala dielo vel'kého, marxizmu vel'mi blízkeho sociologického myslitela Charlesa Wright Millsa“ (tamže). Tak, popri vyhranených kategóriách marxistická sociológia versus nemarxistická sociológia sa objavuje pomerne neurčitá kategória „sociologickej teórie blízkej k marxizmu“ (tamže), k rozvoju ktorej velmi prispel Mills. Ale tak, ako v prípade „pokrokovosti“, tak aj v tomto prípade zjavne chýbajú kritéria potrebného stupňa blízkosti k marxizmu. Sirácky vlastne konštatuje to, čo pozorovali u Millsa aj sovietski odborníci, a to teda absenciu 100-percentnej marxistickej alebo komunistickej príslušnosti, ktorú sa pokúša nahradit” „pokrokovostou“ a „progresívnou angažovanostou“. Napokon Mills ani nepotreboval takéto eufemistické nálepky. Za ním boli jeho diela, ktoré doteraz nemožno hodnotit pomocou jednoznačných prívlastkov. Ovela dôležitejšie bolo sa zamysliet nad príčinami konštatovaného Siráckym všeobecného úpadku záujmu o Millsa v Československu na začiatku 70. rokov, čo sa dalo v tom čase pozorovat aj v ZSSR.

V ZSSR vlna intenzívneho záujmu o Millsa začiatkom 70. rokov opadla v súvislosti s velkými politickými zmenami. Prišlo obdobie tak zvanej „stagnácie“. Vážne spoločensko-politické zmeny prežívalo aj Československo, ktoré práve vstúpilo do obdobia „normalizácie“. A. Sirácky, ktorý príliš preceňuje vplyv štruktúrneho funkcionalizmu, o ktorý sa na Slovensku práve nikto nezaujímal, navrhuje hlbšie sa zamysliet' nad Millsovou Sociologickou imagináciou. V tomto svojom záujme o Millsovo najvýznamnejšie dielo je dôsledný. Čo je dôležité, všíma si v ňom na rozdiel od mnohých svojich kolegov, m. i. aj sovietskych, nielen jeho kritický obsah, ale aj to, čo súvisí s jeho posolstvom. Imponuje mu jeho zameranie na otázky všeobecnejšej roviny. Dokonca cituje Millsovo krédo o potrebe 
„chápat človeka nie ako izolovaný fragment, nie ako inteligibilné pole alebo systém v sebe samom. Treba pochopit muža a ženu ako historických a sociálnych faktorov... Na akomkolvek diele alebo probléme pracujete, orientujte ho k centrálnemu a kontinuitnému cielu pre pochopenie štruktúry a tendencií, výtvorov a názorov svojej vlastnej doby, strašného, ale súčasne aj velkolepého sveta ludskej spoločnosti v druhej polovici dvadsiateho storočia“" (Sirácky, 1966, s. 75).

Najmä mu imponuje Millsova schopnost’ „spájat’ sociologickú problematiku, fakty a udalosti so širokým pohladom na svet“ (Sirácky, 1966, s. 141). Práve tú si nachádza uplatnenie sociologická imaginácia, ktorá vystupuje ako spôsob prepojenia výskumu parciálnych, detailných problémov na „nejakú koncepciu sociálnej štruktúry, teóriu vývoja a pokroku..." (tamže). Sirácky dobre si uvedomuje význam sociologickej imaginácie pre udržanie vnútornej integrity sociologickej disciplíny a zachovanie jej väzieb na vonkajšie prostredie. Určitým spôsobom sa postaral o popularizáciu tohto pojmu na Slovensku, kde doteraz vyznieva ako mobilizujúce a zjednocujúce heslo pre sociológov rôznej ideovej príslušnosti. Avšak nejaká plnohodnotná reflexia Millsovej tvorby v podobe monografie doteraz na Slovensku sa neobjavila.

$\mathrm{V}$ tomto zmysle dnešná ruská sociológia, ktorá v 90. rokoch prebrala dedičstvo po sovietskej sociológie, ma predsa v svojom aktíve ešte z 60.-70. rokov niekolko solídnych štúdií a jednu monografiu o Millsovi. V súčasnosti v Rusku sa objavujú občas časopisecké štúdie, ktoré nám pripomínajú neordinárnu osobnost’ vel'kého amerického sociológa a jeho pozoruhodné sociologické dielo. Zároveň upozorňujú na stále nebezpečie byrokratizácie sociológie a ohrozenie jej humanistických základov. Sociologická imaginácia pred tým včasne varovala. Jej varovania neprestali byt’ aktuálnymi ani v dnešných podmienkach, ked' dochádza k zredukovaniu sociológie na servisnú marketingovú disciplínu, zbavenú hlbších ideových ambícií. Za tejto situácie Sociologická imaginácia mení svoju niekdajšiu funkciu a z kritickej zbrane, obrátenej proti príležitostnému teoretickému súperovi, sa stáva humanistickou výzvou a trvalým morálnym posolstvom pre príslušníkov sociologickej disciplíny.

\section{LITERATÚRA}

Andrejeva, G. M. (1965). Sovremennaja buržuaznaja empiričeskaja sociologija. Moskva: Izdatel'stvo Mysl'.

Bachitov, M. Š. (1965). Voprosy socialnogo modelirovanija i amerikanskij strukturnyj funkcionalizm. In Sovremennyj kapitalizm i buržuaznaja sociologija (s. 3-60). Moskva: Izdatel’stvo Mysl'.

Cypnik, L. A. (1964). Sovremennaja buržuaznaja sociologija i jejo kritika R. Millsom. In Marksistskaja i buržuaznaja sociologija. Moskva: Nauka.

Firsov, B. M. (2001). Istorija sovietskej sociologii 1950-1980-ch godov. Sankt-Peterburg: Izdatel'stvo Evropejskogo universiteta v S. Peterburge.

Horowitz, I. L. (1963). An introduction to The New Sociology. In The New Sociology (s. 3-58). New York: Oxford University Press / A Galaxy Books.

Jonin, L. G., \& Osipov, G. V. (eds.) (1979). Istorija buržuaznoj sociologii pervoj poloviny XX veka. Moskva: Izdatel'stvo Náuka.

Korovin, V. F. (1977). Osnovnyje problemy „novoj sociologii“ Rajta Millsa. Moskva: Izdatel’stvo Moskovskogo universiteta.

Kozlova, L. A. (1995). „Socioanaliz“ Čarlza Rajta Millsa. Sociologičeskij žurnal, 4/1995, 155-157.

Mills, C. W. (2000). Letters and autobiographical writings. Ed. by K. Mills, P. Mills. Los Angeles: University of California Press. 
Mills, C. W. (1959a). The Sociological Imagination. New York: Oxford University Press.

Mills, C. W. (1959b). Vlastvujščaja elita. Moskva: Izdatelstvo inostrannoj literatury.

Mills, C. W. (1968). Sociologická imaginace. Praha: Mladá Fronta.

Mills, C. W. (1998). Sociologičeskoje voobraženije. Moskva: Izdatelskij dom Strategija.

Modržinskaja, J. D. (1962). Antikommunizm - otraženije degradacii buržuaznoj ideologii. In: Novejšije prijomy zaščity starogo mira (s. 3-40). Moskva: Izdatel'stvo socialno-ekonomičeskoj literatury.

Modržinskaja, J. D. (1963). Progressivnoje javlenije v sovremennoj amerikanskoj sociologii. Voprosy filosofii, 4/1963.

Nikulin, A. M. (2003). Avtobiografičeskaja sociologija Čarlza Rajta Millsa. Sociologičeskij žurnal, 4/2003, 165-177.

Ritzer, G. (1988). Contemporary Sociological Theory. New York: McGraw-Hill.

Rossijskaja sociologija šestidesjatych godov v vospominanijach i dokumentach (1999). Sankt-Peterburg: Russkij christianskij gumanitarnyj institut.

Sirácky, A. (1966). Sociológia: Teória, metódy, problémy. Bratislava: Vydavatel'stvo Slovenskej akadémie vied.

Sirácky, A. (1971). C. Wright Mills a angažovaná sociológia. Sociologický časopis / Czech Sociological Review, 7(1), 16-24. 